\title{
Hepatic Subcellular Fractions Lipids in Rats Fed Millet (Sorghum vulgarie) at Different Protein Levels ${ }^{\dagger}$
}

\author{
Rama Misra, ${ }^{*}$ U. K. Misra and T. A. Venkitasubramanian \\ Department of Radioisotopes and Biochemistry, Vallabhbhai Patel Chest Institute, \\ University of Delhi, Delhi 110 007, India
}

Received April 30, 1974

\begin{abstract}
Effect of feeding defatted millet (Sorghum vulgarie) flour at 5, 10 and $14.5 \%$ protein levels respectively for six weeks has been studied on rat liver mitochondrial, microsomal and supernatant fractions total lipids, cholesterol, triglycerides, total phospholipids, phosphatidyl choline and phosphatidyl ethanolamine. The results have been compared with rats fed casein at $10 \%$ level for the same period. The metabolism of liver subcellular fractions lipids of millet diet and casein diet fed rats has been studied by the incorporation of acetate-1 $1{ }^{14} \mathrm{C}$ and $\mathrm{NaH}_{2}$ ${ }^{32} \mathrm{PO}_{4}$. A significant increase in mitochondrial triglycerides of rats fed millet diet at 5 and $10 \%$ protein level, in microsomes of rats fed millet diet at 5, 10 and $15 \%$ protein levels and in supernatant fractions of rats fed millet diet at 5 and $15 \%$ protein levels was observed. A significant increase in total cholesterol in mitochondria and microsomes and a significant decrease in supernatant fraction of rats fed millet diet at $10 \%$ protein level was observed. A significant increase in mitochondrial total phospholipids, phosphatidyl choline and phosphatidyl ethanolamine in rats fed millet diet at $10 \%$ protein level and a decrease in these in rats fed millet diet at 5 per cent protein level was observed. In microsomes total phospholipids were increased in rats millet diet at $10 \%$ protein level and phosphatidyl choline was increased in rats fed millet diet at $15 \%$ protein level. Total phospholipids, phosphatidyl choline and phosphatidyl ethanolamine were significantly reduced in the supernatant fraction of rats fed millet at $10 \%$ protein level.

Incorporation of acetate-1-14 $\mathrm{C}$ into nonsaponifiable fraction of mitochondria, microsomes and supernatant fractions of rats fed millet diet at 5 and $15 \%$ protein levels was significantly greater, and in saponifiable fractions of the above subcellular fractions was greater in rats fed millet diet at 5 per cent protein level. The specific activity (counts $/ \mathrm{min} / \mathrm{mg}$ ) of free cholesterol in mitochondria, microsomes and supernatant fractions of millet diet fed rats was significantly greater, whereas the specific activity of triglycerides was not significantly different from the controls. The acetate-1 $1{ }^{14} \mathrm{C}$ specific activity of phosphatidyl choline and phosphatidyl ethanolamine was significantly greater in all the above subcellular fractions of millet diet fed rats (except of phosphatidyl choline in rats fed millet diet at $5 \%$ protein level). The $\mathrm{NaH}_{2}{ }^{32} \mathrm{PO}_{4}$ specific activities of phosphatidyl choline were significantly greater in mitochondria of rats fed millet diet at $5 \%$ protein level and of phosphatidyl choline and phosphatidyl ethanolamine in microsomes and supernatant fractions of rats fed millet diet at 5 and $15 \%$ protein levels. The specific activities of phosphatidyl choline were significantly decreased in mitochondria and microsomes of rats fed millet diet at $10 \%$ protein level. The total acetate-1-14 $\mathrm{C}$ activities (counts $/ \mathrm{min} / \mathrm{g}$ equivalent wet liver) of free and esterified cholesterol triglycerides, phosphatidyl choline and phosphatidyl ethanolamine showed that their synthesis from acetate${ }_{1-14} \mathrm{C}$ was either enhanced in millet diet fed rats or was comparable to the controls. The total activity of $\mathrm{NaH}_{2}{ }^{32} \mathrm{PO}_{4}$ (counts $/ \mathrm{min} / \mathrm{g}$ equivalent wet liver) into phosphatidyl choline and phosphatidyl ethanolamine showed that their synthesis was decreased in microsomes of rats fed millet diet at $10 \%$ protein level, increased in rats fed millet diet at 5 and $15 \%$ protein levels.
\end{abstract}

Partial deprivation of protein has been shown to affect the rat liver mitochondria fatty

+ Taken in part from Ph.D. thesis of Mrs. Rama Misra, Delhi University (1969). acids, phospholipid to protein ratio and alterations in the amounts of phosphatidyl choline (PC) and phosphatidyl ethanolamine (PE) in mitochondria and microsomes. ${ }^{1 \sim 7)}$ Rats 
fed low casein diets showed an increased mitochondrial swelling, changes in oxidative phosphorylation $^{1)}$ and altered labelling of mitochondrial and microsomal PC and PE with $\mathrm{NaH}_{2}{ }^{32} \mathrm{PO}_{4}{ }^{4 \sim 6)}$ Since the quality of a protein depends on the proportions of its essential amino acids, therefore the effects of feeding plant proteins, which are not only low in protein contents but also have limiting and excess amino acids, will be influenced both by the quantity and the quality of the protein. ${ }^{8)}$ With this view, we have studied the effects of feeding millet (Sorghum vulgarie), a plant protein at different protein levels to rats for six weeks on their liver mitochondrial, microsomal and supernatant fractions lipid metabolism and the results are presented.

\section{EXPERIMENTAL}

Male rats (Wistar strain) weighing $90 \sim 100 \mathrm{~g}$ were used in this experiments. Forty eight rats were divided in four groups of 12 rats each. Rats were housed in individual cages. Three groups of rats were fed ad libitum diets containing defatted millet flour (total protein contents $14.5 \%$ ) at 5, 10 and $14.5 \%$ protein levels respectively (referred in the paper as $\mathrm{M}-5 \%, \mathrm{M}-10 \%$ and $\mathrm{M}-15 \%$ respectively) for a period of six weeks. The fourth group was fed casein at $10 \%$ level for the same period and was the control. The details of the diet preparation, feeding schedule, food consumption and growth rate are described in an earlier paper.9' At the end of six weeks, six rats in each group were intraperitoneally injected with a saline solution of sodium acetate-1-14 $\mathrm{C}(10 \mu \mathrm{Ci} / 100 \mathrm{~g}$ body weight, specific activity $12.66 \mathrm{mCi} / \mathrm{mm}$, obtained from Bhabha Atomic Research Centre, Bombay). The remaining six rats in each group were injected intraperitoneally with a saline solution of $\mathrm{NaH}_{2}{ }^{32} \mathrm{PO}_{4}$ $(100 \mu \mathrm{Ci} / 100 \mathrm{~g}$ body weight, obtained from Bhabha Atomic Research Centre, Bombay). Rats were sacrificed three hours after the administration of the isotopes, their livers removed, immersed in ice-cold saline, cleaned, wiped and weighed. A weighed portion of liver was removed for lipid isolation ${ }^{10 !}$ and another weighed portion was used for the isolation of subcellular fractions viz. mitochondrial, microsomal and supernatant.11,12) The particulate fractions and supernatant fractions were made up to a known volume in $0.25 \mathrm{~m}$ sucrose. The mitochondrial and microsomal fractions were assayed for glucose-6-phosphatase activity. ${ }^{13}$ The results showed that the microsomal fraction contained $85 \sim 88 \%$ of the total activity of glucose-6-phosphatase in liver homogenate and the remaining was present in mitochondria. No corrections in the results were made for this."- Lipids from subcellular fractions were isolated, ${ }^{101}$ and assayed for total lipids (gravimetrically), cholesterol, ${ }^{14)}$ and phospholipid phosphorus. ${ }^{15)}$ The fractionation of subcellular fractions lipids into neutral and phospholipid fractions was done by means of thin-layer chromatography on silica gel $G$ as described earlier.16) For determining ${ }^{14} \mathrm{C}$-radioactivity of subcellular fractions neutral lipids and phospholipid fractions, they were eluted from TLC plates with chloroform and chloroform: methanol: formic acid: water (97:97:4:2, $\mathrm{v} / \mathrm{v} / \mathrm{v} / \mathrm{v})$ respectively), ${ }^{17}$ evaporated to dryness and dissolved in a known volume of chloroform. An aliquot was pipetted into stainless steel planchet dried and counted in a gas flow windowless GM counter (Tracerlab, Waltham, Mass., U.S.A.) and other respective aliquots were assayed for cholesterol, ${ }^{14}$ ) triglycerides ${ }^{18)}$ and phospholipids. ${ }^{15 !}$ The ${ }^{82} \mathrm{Pi}$ radioactivity of phospholipid fractions was determined as described earlier. ${ }^{19)}$ A portion of each subcellular fractions total lipids was saponified with $30 \%$ alcoholic $\mathrm{KOH}$ at $80^{\circ} \mathrm{C}$ for $4 \mathrm{hr}$. After cooling $5 \mathrm{ml}$ of water was added to the alkali hydrolysate and it was repeatedly extracted with petroleum ether (bp $40 \sim 60^{\circ} \mathrm{C}$ ) to remove nonsaponifiable fraction. After petroleum ether extraction, the alkali hydrolysate was acidified to $\mathrm{pH}$ 2.0 with concentrated $\mathrm{H}_{2} \mathrm{SO}_{4}$ and extracted repeatedly with ether. The nonsaponifiable and saponifiable fractions were separately washed twice with distilled water, reduced to dryness and dissolved in a known volume of chloroform. An aliquot of these fractions was used for cholesterol ${ }^{14)}$ and fatty acid estimation ${ }^{201}$ respectively and on another aliquot ${ }^{14} \mathrm{C}$-radioactivity was determined as described above.

\section{RESULTS}

Effect of feeding defatted millet flour at different protein levels to rats for six weeks on the neutral and phospholipids of liver mitochondrial, microsomal and supernatant fractions is shown in Tables I and II.

\section{Mitochondrial lipids}

A significant increase in mitochondrial total lipids, triglycerides and total and esterified cholesterol was observed in rats of $\mathrm{M}-10 \%$ group as compared to the controls (Table I). In rats of $\mathrm{M}-5 \%$ group mitochondrial triglycerides (TG) were increased and esterified cholesterol decreased as compared to the controls (Table I). In rats of $\mathrm{M}-15 \%$ total and 
Table I. Neutral Lipids of LIVER Mitochondria, Microsomes and Supernatant

Fractions of Rats Fed Casein and Millet Diet

Values are mean \pm S.E. from 12 animals in each group.

\begin{tabular}{|c|c|c|c|c|c|}
\hline \multirow{4}{*}{$\begin{array}{c}\begin{array}{c}\text { Subcellular } \\
\text { fraction }\end{array} \\
\text { Mitochondria }\end{array}$} & \multirow[b]{2}{*}{ Lipids } & \multirow[b]{2}{*}{ Control } & \multicolumn{2}{|c|}{ Dietary group } & \multirow[b]{2}{*}{$\mathrm{M}-15 \%$} \\
\hline & & & \multicolumn{2}{|c|}{$\begin{array}{c}\mathrm{M}-5 \% \\
\mathrm{mg} / \mathrm{g} \text { equivalent wet liver }\end{array}$} & \\
\hline & Total lipids & $6.94 \pm 0.18$ & $6.48 \pm 0.57$ & $15.16 \pm 1.45^{a)}$ & $6.66 \pm 0.29$ \\
\hline & Total cholesterol & $0.42 \pm 0.03$ & $0.34 \pm 0.02$ & $0.83 \pm 0.05^{a}$ & $0.27 \pm 0.03^{a i}$ \\
\hline & Free cholesterol & $0.11 \pm 0.01$ & $0.20 \pm 0.03$ & $0.17 \pm 0.04$ & $0.17 \pm 0.09$ \\
\hline & Esterified cholesterol & $0.30 \pm 0.05$ & $0.12 \pm 0.04^{a}$ & $0.65 \pm 0.0$ & 0.10 \\
\hline \multirow{5}{*}{ Microsomes } & mignceriue & & 17 C 80 & $8.30 \pm$ & $1.09 \pm 0.23$ \\
\hline & Total cholesterol & $\begin{array}{r}16.84 \pm 0.33 \\
1.28+0.53\end{array}$ & $\begin{array}{r}1.05 \pm 0.08 \\
1.40+0.03\end{array}$ & $\begin{array}{r}29.34 \pm 2.28^{a} \\
2.19+0.16^{a)}\end{array}$ & $\begin{array}{c}22.23 \pm 0.82^{\alpha 1} \\
1.66+0.09\end{array}$ \\
\hline & Free cholesterol & $0.87 \pm 0.16$ & $0.90 \pm 0.11$ & $1.78 \pm 0.19$ & $1.29 \pm 0.14$ \\
\hline & Esterified cholesterol & $0.37 \pm 0.07$ & $0.41 \pm 0.02$ & $0.41 \pm 0.05$ & $0.37 \pm 0.06$ \\
\hline & Triglycerides & $2.81 \pm 0.15$ & $3.81 \pm 0.12^{a 1}$ & $9.59 \pm 0.22^{a 1}$ & $\left.5.68 \pm 1.39^{a}\right)$ \\
\hline \multirow{5}{*}{ Supernatant } & Total lipids & $11.96 \pm 0.72$ & $17.47 \pm 1.42^{a)}$ & $9.19 \pm 1.61^{a 1}$ & $15.78 \pm 0.75^{a}$ \\
\hline & Total cholesterol & $0.78 \pm 0.03$ & $0.57 \pm 0.06$ & $0.32 \pm 0.09^{\circ 1}$ & $0.72 \pm 0.07$ \\
\hline & Free cholesterol & $0.38 \pm 0.04$ & $0.28 \pm 0.08$ & $0.16 \pm 0.01^{a 1}$ & $0.39 \pm 0.11$ \\
\hline & Esterified cholesterol & $0.39 \pm 0.01$ & $0.29 \pm 0.03$ & $0.16 \pm 0.01^{a}$ & $0.33 \pm 0.09$ \\
\hline & Triglycerides & $6.16 \pm 0.22$ & $10.64 \pm 0.92^{a}$ & $5.11 \pm 0.23^{a}$ & $9.99 \pm 1.12^{a 1}$ \\
\hline
\end{tabular}

a) Values significantly different from the controls at $5 \%$ level.

Table II. Phospholipids of Liver Mitochondria, Microsomes and Supernatant

Fractions of Rats Fed Casein and Millet Diets

Values are mean \pm S.E. from 12 animals in each group.

\begin{tabular}{|c|c|c|c|c|}
\hline \multirow{2}{*}{$\begin{array}{l}\text { Subcellular fractions } \\
\text { phospholipid }\end{array}$} & \multirow[b]{2}{*}{ Control } & \multicolumn{2}{|c|}{ Dietary groups } & \multirow[b]{2}{*}{$\mathrm{M}-15 \%$} \\
\hline & & $\mathrm{M}-5 \%$ & $\mathrm{M}-10 \%$ & \\
\hline Mitochondria & \multicolumn{4}{|c|}{$\mu \mathrm{g}$ phospholipid phosphorus/g equivalent wet liver } \\
\hline $\begin{array}{l}\text { Total phospholipids } \\
\text { Monophosphatidyl inositol }\end{array}$ & $\begin{aligned} 162.8 & \pm 8.4 \\
1.98 & \pm 0.30\end{aligned}$ & $\begin{array}{r}114.8 \pm 5.2^{a)} \\
1.47 \pm 0.17\end{array}$ & $\begin{array}{r}\left.285.6 \pm 18.4^{a}\right) \\
\left.8.15 \pm 1.08^{a}\right)\end{array}$ & $\begin{array}{r}126.4 \pm 12.6 \\
1.42 \pm 0.27\end{array}$ \\
\hline Phosphatidyl serine + lysophosphatidyl & $5.15 \pm 1.19$ & $2.16 \pm 0.62^{a)}$ & $7.60 \pm 0.61$ & $3.74 \pm 0.74$ \\
\hline $\begin{array}{l}\text { Lysophosphatidyl ethanolamine }+ \\
\text { sphingomyelin } \\
\text { Phosphatidyl choline } \\
\text { Phosphatidyl ethanolamine }\end{array}$ & $\begin{array}{l}10.00 \pm 1.57 \\
42.25 \pm 3.81 \\
34.42 \pm 1.47\end{array}$ & $\begin{array}{r}6.80 \pm 0.41^{a} \\
30.97 \pm 3.18^{a 1} \\
19.30 \pm 2.35^{a 1}\end{array}$ & $\begin{array}{l}19.67 \pm 3.05^{a} \\
72.09 \pm 11.81^{a} \\
56.64 \pm 2.65^{a}\end{array}$ & $\begin{array}{l}6.77 \pm 0.94 \\
37.31 \pm 10.82 \\
22.15 \pm 5.13\end{array}$ \\
\hline $\begin{array}{l}\text { Phosphatidic acid }+ \\
\text { polyglycerophosphatide }\end{array}$ & $7.87 \pm 0.26$ & $10.65 \pm 0.81$ & $14.77 \pm 1.52^{a !}$ & $7.56 \pm 2.10$ \\
\hline \multicolumn{5}{|l|}{ Microsomes } \\
\hline $\begin{array}{l}\text { Total phospholipids } \\
\text { Monophosphatidyl inositol }\end{array}$ & $\begin{array}{r}405.6 \pm 20.4 \\
2.89 \pm 0.45\end{array}$ & $\begin{array}{r}413.6 \pm 16.8 \\
4.32 \pm 0.82\end{array}$ & $\begin{array}{r}540.0 \pm 33.6^{a 1} \\
18.40 \pm 2.52^{a)}\end{array}$ & $\begin{array}{r}492.8 \pm 28.4 \\
6.79 \pm 1.59\end{array}$ \\
\hline Phosphatidyl serine + lysophosphatidyl & $14.33 \pm 2.75$ & $17.38 \pm 2.11$ & $47.17 \pm 10.61^{a)}$ & $16.57 \pm 1.74$ \\
\hline $\begin{array}{l}\text { Lysophosphatidyl ethanolamine }+ \\
\text { sphingomyelin } \\
\text { Phosphatidyl choline } \\
\text { Phosphatidyl ethanolamine }\end{array}$ & $\begin{array}{r}38.92 \pm 4.51 \\
122.05 \pm 8.97 \\
68.06 \pm 6.33\end{array}$ & $\begin{array}{c}35.86 \pm 3.45 \\
135.37 \pm 12.76 \\
52.30 \pm 6.22\end{array}$ & $\begin{array}{l}61.05 \pm 11.11^{a)} \\
138.37 \pm 6.25 \\
50.04 \pm 11.71\end{array}$ & $\begin{array}{c}42.81 \pm 6.10 \\
\left.164.74 \pm 0.32^{a}\right) \\
67.68 \pm 10.36\end{array}$ \\
\hline $\begin{array}{l}\text { Phosphatidic acid }+ \\
\text { polyglycerophosphatides }\end{array}$ & $5.71=0.59$ & $11.42 \pm 1.10^{a)}$ & $12.50 \pm 1.30^{a}$ & $8.49 \pm 1.38$ \\
\hline Supernatant & $134.0 \pm 8.0$ & & & $133.0=$ \\
\hline $\begin{array}{l}\text { Total phospholipids } \\
\text { Monophosphatidyl inositol } \\
\text { Phosphatidyl serine + lysophosph }\end{array}$ & & $1.46 \pm 0.26$ & $5.78 \pm 1.53^{a)}$ & \\
\hline $\begin{array}{l}\text { Phosphatidyl serine + lysophosphatidyl } \\
\text { choline }\end{array}$ & $3.48 \pm 0.76$ & $2.50 \pm 0.45$ & $7.12 \pm 2.08$ & $6.84 \pm 2.54$ \\
\hline $\begin{array}{l}\text { Lysophosphatidyl ethanolamine }+ \\
\text { sphingomyelin } \\
\text { Phosphatidyl choline } \\
\text { Phosphatidyl ethanolamine }\end{array}$ & $\begin{array}{l}12.38 \pm 1.70 \\
44.73 \pm 2.83 \\
19.01 \pm 1.10\end{array}$ & $\begin{array}{l}7.39 \pm 1.70 \\
56.63 \pm 3.60 \\
18.76 \pm 2.27\end{array}$ & $\begin{array}{r}9.46 \pm 3.25 \\
16.86 \pm 6.76^{a 1} \\
5.84 \pm 2.04^{a}\end{array}$ & $\begin{array}{r}6.81 \pm 3.29 \\
51.03 \pm 6.47 \\
14.77 \pm 3.39\end{array}$ \\
\hline $\begin{array}{l}\text { Phosphatidic acid }+ \\
\text { polyglycerophosphatide }\end{array}$ & $3.05 \pm 0.39$ & $4.39 \pm 1.42$ & $2.15 \pm 0.38$ & $2.18 \pm 0.55$ \\
\hline
\end{tabular}

a) Values significantly different from the controls at $5 \%$ level. 
esterified cholesterol showed a decrease but total lipids and TG were not significantly different from the controls (Table I). In rats fed millet diet at $5 \%$ protein level a significant reduction in mitochondrial total phospholipids, phosphatidyl choline (PC), phosphatidyl ethanolamine (PE) was observed as compared to the controls (Table II). Total phospholipids, $\mathrm{PC}$ and $\mathrm{PE}$ were significantly increased in rats of $\mathrm{M}-10 \%$ group, whereas these were not significantly different from the controls in rats of $\mathrm{M}-15 \%$ group (Table II). Feeding of millet diet at different protein levels significantly affected the mitochondrial minor phospholipid constituents viz. monophosphatidyl inositol (MPI), phosphatidyl serine (PS)+ lysophosphatidyl choline (LPC), lysophosphatidyl ethanolamine (LPE) + sphingomyelin (SPH), phosphatidic acid (PA) + polyglycerophosphatides (PGP) as compared to the controls (Table II). Mitochondrial PA+PGP fraction showed an increase whereas PS +LPC, $\mathrm{LPE}+\mathrm{SPH}$ were decreased in rats of $\mathrm{M}-5 \%$ group (Table II). In rats of $\mathrm{M}-10 \%$ group MPI, LPE+SPH and PA+PGP fractions were significantly increased as compared to the controls (Table II).

\section{Microsomal lipids}

A significant increase in the amounts of microsomal total lipids and TG was noted in rats of $\mathrm{M}-10 \%$ and $\mathrm{M}-15 \%$ groups as compared to the controls (Table I). Microsomal TG in rats of $\mathrm{M}-5 \%$ group also showed a significant increase (Table I). Total cholesterol in microsomes of $\mathrm{M}-10 \%$ group was significantly higher than the control. (Table I). Except for a significant increase in total phospholipids of $\mathrm{M}-10 \%$ group and in $\mathrm{PC}$ of $\mathrm{M}-15 \%$ microsomal major phospholipids were not significantly affected by feeding millet diet at different protein levels as compared to the controls (Table II). Among minor phospholipids MPI, PS + LPC, $\mathrm{LPE}+\mathrm{SPH}$ and $\mathrm{PA}+$ PGP were increased in rats of $\mathrm{M}-10 \%$ group, and PA+PGP was increased in rats of $\mathrm{M}-5 \%$ group as compared to the controls (Table II).

\section{Supernatant lipids}

In rats of $\mathrm{M}-5 \%$ and $\mathrm{M}-15 \%$ groups total lipids were significantly increased as compared to the controls (Table I). TG were increased in rats of $\mathrm{M}-5 \%$ group and total, free (FC) and esterified cholesterol (EC) were decreased in rats of $\mathrm{M}-10 \%$ as compared to the controls (Table I). Except for a significant decrease in total lipids, phospholipids, PC, PE and MPI in rats of $\mathrm{M}-10 \%$ group, supernatant major and minor phospholipids in other groups were not significantly different from the controls (Table II).

\section{Incorporation of acetate- $1-{ }^{14} \mathrm{C}$ radioactivity}

Non-saponifiable and saponifiable fractions. The effect of feeding millet diet at different protein levels on the utilization of acetate-1${ }^{14} \mathrm{C}$ for the synthesis of cholesterol (nonsaponifiable) and fatty acids (saponifiable) in liver subcellular fractions is shown in Table III. An increased incorporation of acetate-1${ }^{14} \mathrm{C}$ radioactivity into non-saponifiable fraction in mitochondria and microsomes of rats of $\mathrm{M}-5 \%$ and $\mathrm{M}-15 \%$ group and in supernatant fraction of $\mathrm{M}-5 \%, \mathrm{M}-10 \%$ and $\mathrm{M}-15 \%$ group was observed as compared to the controls (Table III). The incorporation of acetate- $1 .{ }^{14} \mathrm{C}$ into mitochondrial fatty acids was increased in rats of $\mathrm{M}-5 \%$ groups and decreased in rats of $\mathrm{M}-10 \%$ group as compared to the controls (Table III). The incorporation of acetate-1${ }^{14} \mathrm{C}$ was significantly increased into microsomal fatty acids of $\mathrm{M}-5 \%$ and $\mathrm{M}-15 \%$ groups and in supernatant fatty acids of rats of M-5\% group as compared to the control (Table III).

\section{Neutral lipids}

A significantly increased incorporation of acetate- $1-{ }^{14} \mathrm{C}$ (counts $/ \mathrm{min} / \mathrm{mg}$ ) into both $\mathrm{FC}$ and $\mathrm{EC}$ in mitochondria of $\mathrm{M}-5 \%$ and $\mathrm{M}-15 \%$ groups and into $\mathrm{FC}$ in mitochondria of $\mathrm{M}$ $10 \%$ group was observed as compared to the controls (Table IV). The incorporation of acetate- $1{ }^{14} \mathrm{C}$ into $\mathrm{FC}$ in microsomes of $\mathrm{M}$ $5 \%, \mathrm{M}-10 \%$ and $\mathrm{M}-15 \%$ groups and into EC of M-15\% group was observed as com- 
Table III. Incorporation of ACETATe-1-14 C Into Liver Mrtochondrial, Microsomal and Supernatant Fractions Saponifiable and Nonsaponifiable Lipids of Rats Fed Casein and Mrllet Diets

Values are mean \pm S.E. from 6 animals in each group.

\begin{tabular}{|c|c|c|c|c|}
\hline \multirow{2}{*}{$\begin{array}{l}\text { Subcellular } \\
\text { fraction }\end{array}$} & \multicolumn{4}{|c|}{ Dietary groups } \\
\hline & Control & $M-5 \%$ & $\mathrm{M}-10 \%$ & $\mathrm{M}-15 \%$ \\
\hline & \multicolumn{4}{|c|}{ counts $/ \mathrm{min} / \mathrm{mg}$ (specific activity) } \\
\hline & \multicolumn{4}{|c|}{ Nonsaponifiable fraction } \\
\hline Mitochondria & $1946 \pm 223$ & $3459 \pm 140^{a}$ & $2003 \pm 137$ & $4860 \pm 681^{a l}$ \\
\hline Microsomes & $1387 \pm 69$ & $2364 \pm 236^{a !}$ & $1914 \pm 129$ & $3656 \pm 614^{a)}$ \\
\hline \multirow[t]{2}{*}{ Supernatant } & $1017 \pm 66$ & $4617 \pm 812^{a}$ & $3026 \pm 371^{a 1}$ & $2550 \pm 1033^{a 1}$ \\
\hline & \multicolumn{4}{|c|}{ Saponifiable fraction } \\
\hline Mitochondria & $267 \pm 14$ & $423 \pm 6^{a 1}$ & $153 \pm 18^{a}$ & $150 \pm 34$ \\
\hline Microsomes & $336 \pm 16$ & $963 \pm 61^{a 1}$ & $309 \pm 33$ & $546 \pm 9^{\alpha}$ \\
\hline Supernatant & $369 \pm 6$ & $936 \pm 92^{a 1}$ & $420 \pm 40$ & $402 \pm 27$ \\
\hline
\end{tabular}

a) Values significantly different from the controls at $5 \%$ level.

Table IV. Incorporation of Acetate-1-14C Into Liver Mitochondrial, Microsomal and Supernatant Fractions Neutral Lipids of Rats Fed Casein AND MILleT DIET

Values are mean \pm S.E. from 6 animals in each group.

\begin{tabular}{|c|c|c|c|c|}
\hline \multirow{2}{*}{$\begin{array}{l}\text { Subcellular fraction } \\
\text { Lipid }\end{array}$} & \multicolumn{4}{|c|}{ Dietary groups } \\
\hline & Control & $\mathrm{M}-5 \%$ & $\mathrm{M}-10 \%$ & $M-15 \%$ \\
\hline & \multicolumn{4}{|c|}{ counts $/ \min / \mathrm{mg}$ (specific activity) } \\
\hline \multicolumn{5}{|l|}{ Mitochondria } \\
\hline Free cholesterol & $617 \pm 68$ & $1119 \pm 102^{a !}$ & $1094 \pm 100^{a}$ & $1623 \pm 180^{a)}$ \\
\hline Esterified cholesterol & $723 \pm 74$ & $1988 \pm 184^{a !}$ & $685 \pm 83$ & $2401 \pm 260^{a}$ \\
\hline Triglycerides & $230 \pm 23$ & $323 \pm 66$ & $353 \pm 66$ & $195 \pm 27$ \\
\hline \multicolumn{5}{|l|}{$\begin{array}{l}\text { Triglycerides } \\
\text { Microsomes }\end{array}$} \\
\hline Free cholesterol & $473 \pm 49$ & $1115 \pm 121^{a l}$ & $689 \pm 83^{a}$ & $951 \pm 72^{a}$ \\
\hline Esterified cholesterol & $800 \pm 82$ & $908 \pm 93$ & $772 \pm 71$ & $2152+188^{a}$ \\
\hline Triglycerides & $267 \pm 43$ & $281 \pm 22$ & $303 \pm 30$ & $604 \pm 200$ \\
\hline \multicolumn{5}{|l|}{$\begin{array}{l}\text { Triglycerides } \\
\text { Supernatant }\end{array}$} \\
\hline Free cholesterol & $430 \pm 42$ & $1724 \div 178^{a}$ & $1632 \pm 173^{a)}$ & $3284 \pm 175^{a}$ \\
\hline Esterified cholesterol & $383 \pm 85$ & $1495 \pm 39^{a 1}$ & $1166 \pm 187^{a .1}$ & $2106 \pm 178^{a)}$ \\
\hline Triglycerides & $283 \pm 28$ & $358 \pm 37$ & $255 \pm 72$ & $388 \pm 49$ \\
\hline
\end{tabular}

a) Values significantly different from the controls at $5 \%$ level.

pared to the controls (Table IV). In supernatant fraction, the incorporation of acetate$1-{ }^{14} \mathrm{C}$ into both $\mathrm{FC}$ and $\mathrm{EC}$ was significantly greater in millet diet fed rats than that of the controls (Table IV). The incorporation of acetate- $1{ }^{14} \mathrm{C}$ (counts $/ \mathrm{min} / \mathrm{mg}$ ) into mitochondrial, microsomal and supernatant fractions TG of millet diet fed rats was not significantly different from the controls (Table IV).

\section{Phospholipids}

The incorporation of acetate $-1{ }^{14} \mathrm{C}$ (counts/ $\mathrm{min} / \mathrm{mg}$ ) into liver mitochondrial, microsomal and supernatant fractions major phospholipids viz. $P C$ and $P E$ of control and millet diet fed rats is shown in Table V. The radioactivity of phospholipid fractions would essentially represent the esterification of newly synthesized fatty acids from acetate- $1-{ }^{14} \mathrm{C}$. The incorporation of acetate- $1 .{ }^{14} \mathrm{C}$ (counts $/ \mathrm{min} / \mathrm{mg}$ ) into PC (except in $\mathrm{M}-5 \%$ ) and PE of mito- 
Table V. Incorporation of Acetate- $1-14$ C into Liver Mitochondrial, Microsomal and Supernatant Fractions Phosphatidyl Choline and Phosphatidyl Ethanolamine of Rats Fed Casein and Millet Diets

Values are mean \pm S.E. from 6 animals in each group.

\begin{tabular}{|c|c|c|c|c|}
\hline \multirow{2}{*}{$\begin{array}{l}\text { Subcellular fraction } \\
\text { Phospholipid }\end{array}$} & \multicolumn{4}{|c|}{ Dietary groups } \\
\hline & Control & $\mathrm{M}-5 \%$ & $\mathrm{M}-10 \%$ & $\mathrm{M}-15 \%$ \\
\hline & \multicolumn{3}{|c|}{ counts $/ \mathrm{min} / \mathrm{mg}$} & \\
\hline \multicolumn{5}{|l|}{ Mitochondria } \\
\hline Phosphatidyl choline & $4040 \pm 460$ & $12690 \pm 810^{a 1}$ & $\left.17750 \pm 3650^{a}\right)$ & $15500 \pm 800^{a 1}$ \\
\hline Phosphatidyl ethanolamine & $3100 \pm 340$ & $18600 \pm 1509^{a\}}$ & $\left.15630 \pm 1729^{a}\right)$ & $8640 \pm 624 a 1$ \\
\hline \multicolumn{5}{|l|}{ Microsomes } \\
\hline Phosphatidyl choline & $4030 \pm 450$ & $6030 \pm 590$ & $14550 \pm 1980^{a 1}$ & $6880 \pm 640^{a 1}$ \\
\hline Phosphatidyl ethanolamine & $3520 \pm 270$ & $18220 \pm 1770^{a /}$ & $17440 \pm 1848^{a 1}$ & $8170 \pm 830^{a}$ \\
\hline \multicolumn{5}{|l|}{ Supernatant } \\
\hline Phosphatidyl choline & $5540 \pm 690$ & $35470 \pm 1660^{a}$ & $\left.59800 \pm 13030^{a}\right)$ & $10170 \pm 453^{a 1}$ \\
\hline Phosphatidyl ethanolamine & $4520 \pm 370$ & $47610 \pm 5800^{a}$ & $55030 \pm 2439^{a}$ & $27650 \pm 2355^{a}$ \\
\hline
\end{tabular}

a) Values significantly different from the controls at $5 \%$ level.

chondrial, microsomal and supernatant fractions in rats of $\mathrm{M}-5 \%, \mathrm{M}-10 \%$ and $\mathrm{M}-15 \%$ groups was significantly higher than the controls (Table V).

\section{Incorporation of $\mathrm{NaH}_{2}{ }^{32} \mathrm{PO}_{4}$}

The incorporation of $\mathrm{NaH}_{2}{ }^{32} \mathrm{PO}_{4}$ (counts/ $\mathrm{min} / \mathrm{mg}$ ) into liver mitochondrial, microsomal and supernatant fractions $\mathrm{PC}$ and $\mathrm{PE}$ of casein and millet diet fed rats is shown in Table VI. The incorporation of $\mathrm{NaH}_{2}{ }^{32} \mathrm{PO}_{4}$ into $\mathrm{PC}$ in mitochondria of $\mathrm{M}-5 \%$ group, in microsomes of $\mathrm{M}-5 \%$ and $\mathrm{M}-15 \%$ groups and in supernatant fraction of $\mathrm{M}-5 \%$ and $\mathrm{M}-15 \%$ groups was significantly higher than the controls (Table VI). The incorporation of $\mathrm{NaH}_{2}{ }^{32} \mathrm{PO}_{4}$ into $\mathrm{PC}$ in mitochondria and microsomes in rats of $\mathrm{M}-10 \%$ group was significantly reduced as compared to the controls (Table VI). The incorporation of $\mathrm{NaH}_{2}{ }^{32} \mathrm{PO}_{4}$ into $\mathrm{PE}$ in mitochondrial fraction of $\mathrm{M}-15 \%$ in microsomes and supernatant fraction of $\mathrm{M}-5 \%$ and $\mathrm{M}-15 \%$ was significantly higher than the controls (Table VI).

\section{DISCUSSION}

In liver the synthesis of TG under normal

TABle VI. InCORPoration OF $\mathrm{NaH}_{2}^{32} \mathrm{PO}_{4}$ into Mitochondrial, Microsomal and Supernatant Fractions Phosphatidyl Choline and Phosphatidyl Ethanolamine of Rats Fed Casein and Millet Diets

Values are mean $\pm S$ S.E. from 6 animals in each group.

\begin{tabular}{|c|c|c|c|c|}
\hline \multirow{2}{*}{$\begin{array}{l}\text { Subcellular fractions } \\
\text { Phospholipid }\end{array}$} & \multicolumn{4}{|c|}{ Dietary groups } \\
\hline & Control & $M-5 \%$ & $\mathrm{M}-10 \%$ & $\mathrm{M}-15 \%$ \\
\hline & \multicolumn{4}{|c|}{ counts $/ \mathrm{min} / \mathrm{mg} \times 10^{3}$ (specific activity) } \\
\hline \multicolumn{5}{|l|}{ Mitochondria } \\
\hline Phosphatidyl choline & $147.5 \pm 10.5$ & $245.2 \pm 17.8^{a}$ & $93.0 \pm 10.0^{a}$ & $139.1 \pm 13.2$ \\
\hline Phosphatidyl ethanolamine & $134.1 \pm 14.0$ & $177.5 \pm 30$ & $109.0 \pm 7.3$ & $264.8 \pm 29.8^{a 1}$ \\
\hline \multicolumn{5}{|l|}{ Microsomal } \\
\hline Phosphatidyl choline & $181.8 \pm 10.3$ & $344.1 \pm 16.0^{a)}$ & $105.5 \pm 10.4^{a)}$ & $315.1 \pm 4.0^{a}$ \\
\hline Phosphatidyl ethanolamine & $186.0 \pm 5.8$ & $363.3 \pm 36.3^{a 1}$ & $204.9 \pm 5.6$ & $377.0 \pm 34.2^{a}$ \\
\hline \multicolumn{5}{|l|}{ Supernatant } \\
\hline Phosphatidyl choline & $154.7 \pm 6.2$ & $307.8 \pm 24.2^{a l}$ & $158.0 \pm 4.5$ & $293.5 \pm 27.7^{a 1}$ \\
\hline Phosphatidyl ethanolamine & $215.7 \pm 21.8$ & $321.5 \pm 14.5^{a\}}$ & $167.3 \pm 8.4$ & $494.9 \pm 5.8^{a}$ \\
\hline
\end{tabular}

a) Values significantly different from the controls at $5 \%$ level. 
conditions takes place in the microsomes. ${ }^{211}$ Two pools of TG in rat liver have been identified. ${ }^{22,23)}$ One is the storage pool which contains the bulk of hepatic TG and is associated with the hyaloplasm of hepatocytes. The second, an active pool is associated with the endoplasmic reticulum of hepatocytes where an active esterification of fatty acids to a-glycerophosphate takes place. The latter is also the precursor pool of plasma TG. The secretion of liver TG into plasma as lipoproteins is an extremely coordinated process, where not only the integrity of various cellular organelles taking part in this process is important, but also the synthesis of lipoprotein moieties in appropriate proportions is critical. It has been observed that the accumulation of TG in liver of rats fed millet diet at different protein levels occurs by their enhanced synthesis and normal secretion into plasma, as assessed by palmitate- $1-{ }^{14} \mathrm{C}$ incorporation into liver and plasma TG. $^{24)}$ An increased lipogenesis and increased synthesis of hepatic phospholipids and TG from acetate $-1-{ }^{14} \mathrm{C}$ has also been observed in rats fed millet diet at different protein levels. ${ }^{25)}$ The specific activities (counts $/ \mathrm{min} / \mathrm{mg}$ ) of microsomal TG of millet diet fed rats were not significantly different from the controls (Table IV), because of the expanded pool sizes of TG in millet diet fed rats. However, the total activities (counts $/ \mathrm{min} / \mathrm{g}$ equivalent wet weight) of microsomal TG of $\mathrm{M}-10 \%$ and $\mathrm{M}-15 \%$ groups were significantly greater $(4 \sim 5$ folds $)$ than the controls (Table VII), which indicate an enhanced synthesis of $\mathrm{TG}$ in microsomes of $\mathrm{M}-10 \%$ and $\mathrm{M}-15 \%$ groups. This may account for the increased amounts of TG observed in these groups. Enhanced synthesis of TG and their normal secretion into plasma as lipoproteins has been attributed as one of the factors responsible for increased accumulation of TG in liver under several experimental conditions. $^{26)}$ It has been reported that mitochondria can also synthesize TG. ${ }^{21}$ The specific activities of mitochondrial TG of millet diet fed rats were not significantly different from the controls (Table IV). The mitochondrial $T G$ pool sizes in millet diet fed rats viz $\mathrm{M}-5 \%$ and $\mathrm{M}-10 \%$ were significantly larger than the controls (Table I); and this might have given an unaltered specific activity (SA) of mitochondrial $\mathrm{TG}$ of millet diet fed rats. However the total activities of mitochondrial $\mathrm{TG}$ of $\mathrm{M}-5 \%$ and $\mathrm{M}-10 \%$ were significantly higher than the control (Table

\section{Table VII. Incorporation of Acetate-1-14C into Liver Mitochondrial, Microsomal and Supernatant Fractions Free Cholesterol, Esterified Cholesterol and Triglycerides of Rats Fed Casein and Millet Diets}

Values are mean \pm S.E. from 6 animals in each group.

\begin{tabular}{|c|c|c|c|c|}
\hline \multirow{2}{*}{$\begin{array}{l}\text { Subcellular fraction } \\
\text { Lipids }\end{array}$} & \multicolumn{4}{|c|}{ Dietary groups } \\
\hline & Control & $M-5 \%$ & $\mathrm{M}-10 \%$ & $\mathrm{M}-15 \%$ \\
\hline & \multicolumn{4}{|c|}{ counts/min/g equivalent wet liver (total activity) } \\
\hline \multicolumn{5}{|l|}{ Mitochondria } \\
\hline Free cholesterol & $68 \pm 7$ & $224 \pm 34^{a 1}$ & $186 \pm 20^{a 1}$ & $276 \pm 31^{a !}$ \\
\hline Esterified cholesterol & $217 \pm 22$ & $239 \pm 22$ & $445 \pm 54^{a !}$ & $240 \pm 26$ \\
\hline Triglycerides & $350 \pm 35$ & $743 \pm 75^{a !}$ & $2930 \pm 547^{a 1}$ & $329 \pm 45$ \\
\hline \multicolumn{5}{|l|}{$\begin{array}{l}\text { Triglycerides } \\
\text { Microsomes }\end{array}$} \\
\hline Free cholesterol & $411 \pm 43$ & $1003 \pm 108^{\alpha}$ & $1226 \pm 149^{a !}$ & $1227 \pm 93^{a 1}$ \\
\hline Esterified cholesterol & $296 \pm 30$ & $372 \pm 38$ & $316 \pm 29$ & $796 \pm 69^{a)}$ \\
\hline Triglycerides & $740 \pm 20$ & $1071 \pm 84$ & $2906 \pm 287^{a 1}$ & $3431 \pm 1136^{a}$ \\
\hline \multicolumn{5}{|l|}{$\begin{array}{l}\text { Inglycerides } \\
\text { Supernatant }\end{array}$} \\
\hline Free cholesterol & $155 \pm 15$ & $483 \pm 50^{a 1}$ & $261 \pm 28$ & $1281 \pm 68^{a 1}$ \\
\hline Esterified cholesterol & $138 \pm 30$ & $419 \pm 11^{a 1}$ & $187 \pm 29$ & $695=58^{a}$ \\
\hline Triglycerides & $1743 \pm 172$ & $3809 \pm 393^{a}$ & $1303 \pm 367$ & $3876 \pm 489^{a 1}$ \\
\hline
\end{tabular}

a). Values significantly different from the controls at $5 \%$ level. 
VII) showing their enhanced synthesis which could result in their increased amounts noted in these groups (Table I). The TG synthesized in microsomes contribute to the TG pool of cytoplasm. ${ }^{22,23)}$ Thus the increased pool sizes (Table I), and total acetate $-1-{ }^{14} \mathrm{C}$ activity (Table VII) of TG in supernatant fraction of $\mathrm{M}-5 \%$ and $\mathrm{M}-15 \%$ groups possibly results from an increased contribution from the microsomal TG pool as compared to the controls.

The synthesis of FC in liver occurs chiefly in the microsomes, whereas cholesterol esterifying enzymes are localized in mitochondria and microsomes, both having similar levels of esterifying enzymes. ${ }^{27)}$ The cholesterol hydrolyzing activity is found only in the soluble fraction. ${ }^{27)}$ The increased specific activity (counts $/ \mathrm{min} / \mathrm{mg}$ ) of EC in mitochondria of $\mathrm{M}-5 \%$ and $\mathrm{M}-15 \%$ groups (Table IV) is attributed to its reduced pool size in these groups as compared to the controls (Table I). The total activity of EC in mitochondria of $\mathrm{M}-5 \%$ and $\mathrm{M}-15 \%$ groups was comparable to the controls (Table VII), which suggests that the EC synthetic capacity of mitochondria was not affected in rats fed millet diet. The total acetate $-1-{ }^{14} \mathrm{C}$ activity of EC in mitochondria of $\mathrm{M}-10 \%$ group was significantly greater than the controls (Table VII), showing possibly a reduced loss of the lable from EC, since its SA was not different from the controls (Table IV) but the pool size was significantly larger as compared to the controls (Table I). The pool size of FC in mitochondria of millet diet fed rats were not significantly different from the controls (Table I), but its specific activities (Table IV) as well as total activities (Table VII) were significantly greater than the controls. Since mitochondria do not synthesize free cholesterol, the increased incorporation of acetate- $1-{ }^{14} \mathrm{C}$ into mitochondrial $\mathrm{FC}$ of millet diet fed rats might have resulted from a stimulated exchange from microsomes. The total activity of mitochondrial FC regardless of the amount of protein in the diet was lower than the microsomes (Table VII). Both the increased specific ac- tivities (Table IV) and total activities (Table VII) without significantly different pool sizes (Table I) of FC in microsomes of millet diet fed rats suggest its enhanced synthesis as compared to the controls. Both the increased specific activity (Table IV) and total activity (Table VII) of microsomal EC in M-15\% group show its increased synthesis as compared to the controls. The reduced amounts of EC in supernatant fraction of rats of $\mathrm{M}-10 \%$ group (Table I) might have resulted from its enhanced hydrolysis as compared to the controls. The restricted release of both $\mathrm{FC}$ and EC from microsomes in this group could also result in their observed reduced amounts. Both the increased specific activities (Table IV) and total activities (Table VII) of both $\mathrm{FC}$ and $\mathrm{EC}$ in supernatant fraction of $\mathrm{M}-5 \%$ and $\mathrm{M}-15 \%$ groups suggest their increased turnover as compared to the controls. The significantly increased specific activity of both $\mathrm{EC}$ and $\mathrm{FC}$ in supernatant fraction of $\mathrm{M}-10 \%$ as compared to the controls (Table IV) is attributed to their reduced pool sizes. However, their total activities in this group were comparable to the controls, suggesting that their metabolism was not significantly different from the controls.

Cornatzer and Walser ${ }^{5 /}$ reported a decrease in liver mitochondrial total phospholipids and PC of rats fed low casein diets. Harada and Mogi ${ }^{3}$ ) observed a difference in the phospholipid to protein ratio in mitochondria and supernatant fractions of rats fed $4 \%$ casein diet. Rogers $^{6}$ reported a decrease in PC of liver mitochondria and microsomes and increase in PE of these liver subcellular fractions in rats fed 4 per cent casein diet as compared to rats fed $25 \%$ casein diet. In the present investigation mitocondrial total phospholipids, PC and PE were decreased in rats of $\mathrm{M}-5 \%$ group, increased in rats of $\mathrm{M}-10 \%$ group and remained unaffected in rats of $\mathrm{M}-15 \%$ group as compared to the controls (Table II). In microsomes of $\mathrm{M}-10 \%$ group total phospholipid increased without any change in $\mathrm{PC}$ and $\mathrm{PE}$ and in $\mathrm{M}-15 \%$ group only PC was increased (Table II). In super- 
natant fraction of $\mathrm{M}-10 \%$ group total phospholipids, PC and PE were reduced as compared to the controls (Table II). These differences in the effects of feeding low casein diets and millet diet at different protein levels are attributed to both the quality and quantity of the protein fed viz. millet, which is low in protein content, has limiting lysine, threonine and methionine and excess leucine amino acids.

Inspite of the alterations in the pool sizes of PC and PE in liver mitochondrial, microsomal and supernatant fractions of millet diet fed rats (Table II), the acetate- $1-{ }^{14} \mathrm{C}$ specific activities (counts $/ \mathrm{min} / \mathrm{mg}$ ) of $\mathrm{PC}$ and $\mathrm{PE}$ in these subcellular fractions (except of $\mathrm{PC}$ in microsomes of $\mathrm{M}-5 \%$ group which was comparable to the control) were significantly higher than the controls (Table V). The total activities (counts/min/g equivalent wet liver) of $\mathrm{PC}$ and $\mathrm{PE}$ in the above subcellular fractions of millet diet fed rats (except of PC in supernatant fraction of $\mathrm{M}-5 \%$ group, which was comparable to the control) were also significantly higher than the controls (Table VIII). These results show that the lipogenesis from acetate- $1-{ }^{14} \mathrm{C}$ as well as the esterification of newly synthesized fatty acids from acetate $-1{ }^{14} \mathrm{C}$ to $\alpha$-glycerophosphate to form PC, PE and TG was significantly enhanced in rats fed millet diet at different protein levels. The fatty acid synthesis in mitochondria and microsomes occurs by chain elongation/shortening, whereas the de novo synthesis of fatty acids occurs in soluble portion. ${ }^{28)}$ The reduced specific activities of fatty acids (saponifiable fraction) in mitochondria of $\mathrm{M}-10 \%$ group (Table III) is possibly due to their expanded pool sizes, since both TG and phospholipids were significantly higher in $\mathrm{M}-10 \%$ group as compared to the controls (Tables I and II). The results show that the fatty acid synthesis in liver subcellular fractions of millet diet fed rats was enhanced than the controls.

All the moieties of phospholipids viz. glycerol, fatty acids, phosphate and base, have different turnover rates. The incorporation of acetate- $1{ }^{14} \mathrm{C}$ into $\mathrm{PC}$ and $\mathrm{PE}$ in liver mitochondria, microsomes and supernatant fractions of millet diet fed rats showed that the turnover of acyl moieties of PC and PE was greater than the controls (Tables V and VIII). Harada and Suzuki ${ }^{4)}$ reported an increased incorporation of $\mathrm{NaH}_{2}{ }^{32} \mathrm{PO}_{4}$ into $\mathrm{PC}$ of rat liver mitochondria fed $4 \%$ casein diet. However, Rogers ${ }^{6)}$ observed an increased incorporation of ${ }^{32} \mathrm{P}_{1}$ into both $\mathrm{PC}$ and $\mathrm{PE}$ of liver mitochondria of rats fed low casein diet. In the present investigation the incorporation of $\mathrm{NaH}_{2}{ }^{32} \mathrm{PO}_{4}$ (counts $/ \mathrm{min} / \mathrm{mg}$ ) into $\mathrm{PC}$ of both mitochondria and microsomes of rat fed

Table VIII. Incorporation of Acetate-1-14C into Liver Mitochondrial, Microsomal and Supernatant Fractions Phosphatidyl Ethanolamine Phosphatidyl Choline of Rats Fed Casein and Millet Diets

Values are mean \pm S.E. from 6 animals in each group.

\begin{tabular}{|c|c|c|c|c|}
\hline \multirow{3}{*}{$\begin{array}{l}\text { Subcellular fraction } \\
\text { Phospholipids }\end{array}$} & \multirow[b]{2}{*}{ Control } & \multicolumn{2}{|c|}{ Dietary groups } & \multirow{2}{*}{$\mathrm{M}-15 \%$} \\
\hline & & $\mathrm{M}-5 \%$ & $\mathrm{M}-10 \%$ & \\
\hline & \multicolumn{4}{|c|}{ counts $/$ min/g equivalent wet liver $\times 10^{3}$ (total activity) } \\
\hline Mitochondrial & & & & \\
\hline Phosphatidyl choline & $170.6 \pm 19.3$ & $393.0 \pm 25.0^{a 1}$ & $1279.6 \pm 26.2^{21}$ & $578.3 \pm 29.6^{a)}$ \\
\hline Phosphatidyl ethanolamine & $106.7 \pm 11.5$ & $358.9 \pm 39.6^{a\}}$ & $885.3 \pm 40.8^{a 1}$ & $191.3 \pm 19.2^{a 1}$ \\
\hline \multicolumn{5}{|c|}{$\left.201323+2132^{a}\right) \quad 11334+12\left(3^{a}\right)$} \\
\hline Phosphatidyl choline & $491.8 \pm 47.1$ & $816.3 \pm 14.7^{a 1}$ & $2013.3 \pm 213.2^{a 1}$ & $1133.4 \pm 121.3^{a)}$ \\
\hline Phosphatidyl ethanolamine & $239.6 \pm 18.3$ & $952.9 \pm 37.2$ & $872.7 \pm 42.4^{a 1}$ & $552.9 \pm 14.0^{a 1}$ \\
\hline \multicolumn{5}{|l|}{ Supernatant } \\
\hline Phosphatidyl choline & $247.8 \pm 3.0$ & $2008.7 \pm 92.9^{a 3}$ & $10082.2 \pm 208.4^{a\}}$ & $518.9 \pm 23.1^{a t}$ \\
\hline Phosphatidyl ethanolamine & $85.9 \pm 7.0$ & $321.3 \pm 14.2^{a 1}$ & $321.3 \pm 14.2^{a 1}$ & $408.4 \pm 34.7^{a 1}$ \\
\hline
\end{tabular}

a) Values significantly different from the controls at $5 \%$ level. 
millet diet at $10 \%$ protein level was significantly decreased as compared to the controls (Table VI). However, the specific acitivities of PC was significantly higher in mitochondria of $\mathrm{M}-5 \%$ group; in microsomes and supernatant of $\mathrm{M}-5 \%$ and $\mathrm{M}-15 \%$ groups as compared to the controls (Table VI). The specific activitiy of PE was significantly higher in mitochondria of $\mathrm{M}-15 \%$ group; in microsomes of $\mathrm{M}-5, \mathrm{M}-10 \%$ and $\mathrm{M}-15 \%$ groups and in supernatant of $\mathrm{M}-5 \%$ and $\mathrm{M}-15 \%$ groups as compared to the controls (Table VI). The total activities (counts $/ \mathrm{min} / \mathrm{g}$ equivalent wet liver) of $\mathrm{PC}$ and $\mathrm{PE}$ in liver mitochondria of millet diet fed rats were not significantly different from the control (Table IX). This would suggest that inspite of the altered specific activities of PC and PE (Table VI) which are influenced by their pool sizes (Table II), the uptake of $\mathrm{NaH}_{2}{ }^{32} \mathrm{PO}_{4}$ by $\mathrm{PC}$ and $\mathrm{PE}$ was not significantly different from the controls. The total activities of $\mathrm{PC}$ and $\mathrm{PE}$ in microsomes of $\mathrm{M}-5 \%$ and $\mathrm{M}-15 \%$ groups were significantly greater, than the controls (Table IX). This shows an enhanced synthesis of PC and PE in rats fed millet diet at 5 and $15 \%$ protein levels as compared to the controls. However, the total activity of PC and $\mathrm{PE}$ in microsomes of $\mathrm{M}-10 \%$ group was significantly lower than the controls (Table
IX), showing that the uptake of $\mathrm{NaH}_{2}{ }^{32} \mathrm{PO}_{4}$ by $\mathrm{PC}$ and $\mathrm{PE}$ was significantly reduced in this group. The reduced uptake of $\mathrm{NaH}_{2}{ }^{32} \mathrm{PO}_{4}$ by $\mathrm{PC}$ and $\mathrm{PE}$ in microsomes of $\mathrm{M}-10 \%$ group could possibly result either due to the impaired ATP ${ }^{32} \mathrm{Pi}$ exchange reaction or reduced activities of choline and ethanolamine kinases. Feeding of low protein diets has been shown to induce mitochondrial swelling and alter oxidative phosphorylation, ${ }^{11}$ which may result in the reduced uptake of $\mathrm{NaH}_{2}{ }^{32} \mathrm{PO}_{4}$ by microsomes for the synthesis of PC and PE in rats of M-10\% group. These results also show that the (Tables V, VI, VIII and IX) acyl moieties and phosphate moieties of PC and PE in millet diet fed rats are turning over differently.

Several studies have shown that the microsomes are the site at which the synthesis of $\mathrm{PC}$ and PE occurs. ${ }^{29}$ In vivo incorporation of phosphoryl choline ${ }^{30}$ and fatty acids $^{31)}$ into mitochondrial PC has been demonstrated but the enzyme transferring phosphoryl choline to diglyceride has not been demonstrated to be present in mitochondria. ${ }^{291}$ Similarly the mitochondria do not seem to synthesize $P E$, though substantial amounts of PE are present. Studies on labelling of mitochondrial and microsomal PC and PE have shown that an exchange mechanism is involved with

TABle IX. Incorporation of $\mathrm{NaH}_{2}{ }^{32} \mathrm{PO}_{4}$ Into Liver Mrtochondrial, Microsomal and Supernatant Fractions, Phosphatidyl Choline and Phosphatidyl Ethanolamine of Rats Fed Casein and Millet Diets

Values are mean \pm S.E. from 6 animals in each group.

\begin{tabular}{|c|c|c|c|c|}
\hline \multirow{2}{*}{$\begin{array}{l}\text { Subcellular fractions } \\
\text { Phospholipids }\end{array}$} & \multicolumn{4}{|c|}{ Dietary groups } \\
\hline & Control & $\mathrm{M}-5 \%$ & $\mathrm{M}-10 \%$ & $M-15 \%$ \\
\hline & \multicolumn{4}{|c|}{ counts/min/g equivalent wet liver $\times 10^{3}$ (total activity) } \\
\hline \multicolumn{5}{|l|}{ Mitochondria } \\
\hline Phosphatidyl choline & $62.3 \pm 4.6$ & $75.9 \pm 5.5$ & $67.0 \pm 7.2$ & $51.9 \pm 4.9$ \\
\hline Phosphatidyl ethanolamine & $46.1 \pm 4.8$ & $34.2 \pm 5.7$ & $61.7 \pm 4.1$ & $58.6 \pm 6.6$ \\
\hline \multicolumn{5}{|l|}{ Microsomes } \\
\hline Phosphatidyl choline & $221.8 \pm 12.5$ & $465.8 \pm 21.6^{a 1}$ & $145.9 \pm 15.4^{a)}$ & $519.0 \pm 6.5^{a 1}$ \\
\hline Phosphatidyl ethanolamine & $126.5 \pm 3.9$ & $190.0 \pm 20.5^{a 1}$ & $102.5 \pm 2.8^{a 1}$ & $255.1 \pm 23.1^{a 1}$ \\
\hline \multicolumn{5}{|l|}{ Supernatant } \\
\hline Phosphatidyl choline & $69.2 \pm 2.8$ & $174.3 \pm 13.7^{a}$ & $26.6 \pm 0.7^{a .1}$ & $149.8 \pm 14.1^{a}$ \\
\hline Phosphatidyl ethanolamine & $41.0 \pm 5.4$ & $60.6 \pm 2.7^{a 1}$ & $9.7 \pm 0.4^{a 1}$ & $73.1 \pm 0.8^{a 1}$ \\
\hline
\end{tabular}

a) Values significantly different from the controls at $5 \%$ levels. 
the distribution of ${ }^{32} \mathrm{P}$-labelled $\mathrm{PE}$ and $\mathrm{PC}$ between microsomes and mitochondria. ${ }^{32 \sim 38)}$ This exchange occurs in the presence of high speed supernatant. ${ }^{39}$ In the present investigation similar interpretation can be drawn, since the specific activities of mitochondrial PC and PE were always lower than the microsomal PC and PE (Table VI). This does not appear to be affected by the amount or quality of the protein in the diet. The observed decrease in the total $\mathrm{NaH}_{2}{ }^{32} \mathrm{PO}_{4}$ activity of $\mathrm{PC}$ and $\mathrm{PE}$ in supernatant fraction of $\mathrm{M}-10 \%$ group (Table IX) appear to be due to the reduced labelling of microsomal $\mathrm{PC}$ and $\mathrm{PE}$ of $\mathrm{M}-10 \%$ group. These findings provide evidence that the rat liver mitochondrial, microsomal and supernatant fractions phospholipids which are important both structurally and functionally are affected by both the quantity and quality of the protein fed.

Acknowledgements. Competent technical assistance of Mr. N. Srivastava and Mr. A. K. Jain is acknowledged. This work was supported in part from the PL-480 funds of the United States Department of Agriculture, Washington, DC. (Grant No. FG-In-264, project No. A7-Hn-14).

\section{REFERENCES}

1) N. Harada, J. Nutri., 93, 263 (1967).

2) N. Harada, M. Kurahashi and M. Haga, Agr. Biol. Chem., 33, 168 (1969).

3) N. Harada, and S. Mogi, ibid., 30, 274 (1966).

4) N. Harada and T. Suzuki, ibid., 32, 340 (1968).

5) W. E. Cornatzer and A. H. Walser, Proc. Soc. Exptl. Biol. Med., 116, 893 (1964).

6) C. G. Rogers, J. Nutri., 101, 1547 (1971).

7) C. G. Rogers, Nutri. Rept. Intern., 4, 351 (1971).

8) M. Swaminathan, in "Newer Methods of Nutritional Biochemistry," Vol. 3 ed. A. A. Albanese, Academic Press, New York, p. 197 (1967).

9) R. Misra, U. K. Misra and T. A. Venkitasubramanian, Agr. Biol. Chem., 37, 711 (1973).

10) R. Misra, U. K. Misra and T. A. Venkitasubramanian, ibid, 37, 55 (1973).

11) G. H. Hogeboom, Methods in Enzymol., 1, 16
(1955).

12) W. W. Umbreit, R. H. Burris and S. F. Stanfer, "Manometric Techniques," 3rd ed. Burgess Publishing Co., Minneapolis, p. 10 (1957).

13) A. E. Harper, "Methods of Enzymatic Analysis," ed. H. N. Bergemeyer Academic Press, New York, p. 788 (1965).

14) H. K. Hanel and H. Dam, Acta Chem. Scand., 9, 677 (1955).

15) G. V. Marinetti, J. Lipid Res., 3, 1 (1962).

16) U. K. Misra, Biochim. Biol. Speri., 7, 57 (1968).

17) D. Abramson and M. Blecher, J. Lipid Res., 5, 628 (1964).

18) E. VanHandle and D. B. Zilversmit, J. Lab. Clin. Med., 50, 152 (1957).

19) U. K. Misra, Biochim. Biol. Speri., 8, 125 (1969).

20) A. C. Kibrick and S. J. Skupp, Arch. Biochem. Biophys., 44, 34 (1953).

21) B. Shapiro, in "Lipids and Lipidoses," ed. G. Schettler Springer-Verlag, New York p. 40 (1967).

22) R. J. Havel, J. M. Felts and C. M. VanDuyne, J. Lipid Res., 3, 297 (1962).

23) N. Baker and M. C. Schotz, ibid., 5, 188 (1964).

24) R. Misra, U. K. Misra and T. A. Venkitasubrmanian, Nutri. Metab., 17, 9 (1974).

25) R. Misra, U. K. Misra and T. A. Venkitasubramanian, Nutri. Rept. Intern., 9, 441 (1974).

26) B. Lombardi, Lab. Invest., 15, 1 (1966).

27) D. S. Goodman, Physiol. Rev., 45, 747 (1965).

28) J. Tepperman and H. M. Tepperman, Fed. Proc., 29, 1284 (1970).

29) G. F. Wilgram and E. P. Kennedy, J. Biol. Chem., 238, 2615 (1963).

30) M. Rodbell and D. J. Hanahan, ibid., 214, 607 (1955).

31) R. Bressler and S. J. Friedberg, ibid., 239, 1364 (1964).

32) K. W. A. Wirtz and D. B. Zilversmit, ibid., 243, 3596 (1968).

33) K. W. A. Wirtz and D. V. Zilversmit, Biochim. Biophys. Acta, 187, 486 (1969).

34) W. C. McMurray and R. M. C. Dawson, Biochem. J., 112, 91 (1969).

35) J. L. Holtzman, T. E. Gram and J. R. Gillette, Arch. Biochem. Biophys., 138, 199 (1970).

36) M. Akiyama and T. Sakagami, Biochim. Biophys. Acta, 187, 105 (1969).

37) D. S. Beattie, J. Membrane Biol., 1, 383 (1969).

38) M. Sauner and M. Levy, $J$. Lipid Res., 12, 71 (1971).

39) K. W. A. Wirtz and D. B. Zilversmit, FEBS Letters, 7, 44 (1970). 